\title{
Hillslope Nutrient Dynamics Following Upland Riparian Vegetation Disturbance
}

\author{
J. Alan Yeakley, ${ }^{1 *}$ David C. Coleman, ${ }^{2}$ Bruce L. Haines, ${ }^{3}$ \\ Brian D. Kloeppel, ${ }^{2}$ Judy L. Meyer, ${ }^{2}$ Wayne T. Swank, ${ }^{4}$ Barry W. Argo, ${ }^{2}$ \\ James M. Deal, ${ }^{2}$ and Sharon F. Taylor ${ }^{2}$
}

\begin{abstract}
${ }^{1}$ Environmental Sciences and Resources, Portland State University, Portland, Oregon 97207-0751, USA; ${ }^{2}$ Institute of Ecology, University of Georgia, Athens, Georgia 30602, USA; ${ }^{3}$ Department of Plant Biology, University of Georgia, Athens, Georgia 30602 USA; ${ }^{4}$ Coweeta Hydrologic Laboratory, USDA-Forest Service, Otto, North Carolina 28763, USA
\end{abstract}

\begin{abstract}
We investigated the effects of removing nearstream Rhododendron and of the natural blowdown of canopy trees on nutrient export to streams in the southern Appalachians. Transects were instrumented on adjacent hillslopes in a first-order watershed at the Coweeta Hydrologic Laboratory $\left(35^{\circ} 03^{\prime} \mathrm{N}, 83^{\circ} 25^{\prime} \mathrm{W}\right)$. Dissolved organic carbon (DOC), $\mathrm{K}^{+}, \mathrm{Na}^{+}, \mathrm{Ca}^{2+}, \mathrm{Mg}^{2+}, \mathrm{NO}_{3}{ }^{-}-\mathrm{N}, \mathrm{NH}_{4}{ }^{+}-\mathrm{N}$, $\mathrm{PO}_{4}{ }^{3-}-\mathrm{P}$, and $\mathrm{SO}_{4}{ }^{2-}$ were measured for 2 years prior to disturbance. In August 1995, riparian Rhododendron on one hillslope was cut, removing $30 \%$ of total woody biomass. In October 1995, Hurricane Opal uprooted nine canopy trees on the other hillslope, downing $81 \%$ of the total woody biomass. Over the 3 years following the disturbance, soilwater concentrations of $\mathrm{NO}_{3}{ }^{-}-\mathrm{N}$ tripled on the cut hillslope. There were also small changes in soilwater DOC, $\mathrm{SO}_{4}{ }^{2-}, \mathrm{Ca}^{2+}$, and $\mathrm{Mg}^{2+}$. However, no significant changes occurred in groundwater nutrient concentrations following Rhododendron removal. In contrast, soilwater $\mathrm{NO}_{3}{ }^{-} \mathrm{N}$ on the
\end{abstract}

\section{INTRODUCTION}

Riparian zones in forested watersheds have been defined as locations of direct interaction between

Received 30 January 2001; accepted 25 July 2002.

Current address for B. W. Argo: The Nature Conservancy, Kissimmee, Florida 34759, USA

Current address for S. F. Taylor: Land Trust for the Little Tennessee River, Franklin, North Carolina 28734, USA

*Corresponding author; e-mail: yeakley@pdx.edu storm-affected hillslope showed persistent 500-fold increases, groundwater $\mathrm{NO}_{3}{ }^{-}-\mathrm{N}$ increased four fold, and streamwater $\mathrm{NO}_{3}{ }^{-}-\mathrm{N}$ doubled. Significant changes also occurred in soilwater $\mathrm{pH}, \mathrm{DOC}, \mathrm{SO}_{4}{ }^{2-}$, $\mathrm{Ca}^{2+}$, and $\mathrm{Mg}^{2+}$. There were no significant changes in microbial immobilization of soil nutrients or water outflow on the storm-affected hillslope. Our results suggest that Rhododendron thickets play a relatively minor role in controlling nutrient export to headwater streams. They further suggest that nutrient uptake by canopy trees is a key control on $\mathrm{NO}_{3}{ }^{-} \mathrm{N}$ export in upland riparian zones, and that disruption of the root-soil connection in canopy trees via uprooting promotes significant nutrient loss to streams.

Key words: biogeochemistry; dissolved organic carbon; hillslope hydrology; nutrient uptake; soilwater chemistry; southern Appalachian mountains; streamwater quality; vegetation removal; watershed management; windthrow. aquatic and terrestrial ecosystems, with boundaries extending outward to the limits of flooding or nearsurface saturation and upward into the canopy of streamside vegetation (Gregory and others 1991). Riparian zones typically act as sinks for nutrients in solution moving along subsurface hydrologic flowpaths. Various processes result in nutrient sequestration or loss in riparian zones, including vegetative uptake, soil adsorption, volatilization, and microbial immobilization (Naiman and Décamps 1997). 
The removal of forest vegetation generally causes transient increases in nutrient exports to streams (Johnson and others 1982; Swank 1988; Hornbeck and others 1990). The magnitudes of these increases depend greatly on the method and extent of vegetation removal (Pye and Vitousek 1985; Swank 1988). Streamwater $\mathrm{NO}_{3}{ }^{-}-\mathrm{N}$ is the ion most likely to increase and to persist at elevated levels in streams for years or even decades after cutting (Swank 1988). Most field studies, however, have consisted of whole-watershed experiments; far fewer studies have been done to connect biological and hydrological controls on biogeochemical processes to streams at the hillslope scale.

In the southern Appalachian mountains, the evergreen sclerophyllous ericaceous shrub Rhododendron maximum $\mathrm{L}$. is a mesic understory species that grows primarily near streams. This shrub often acts to completely close the understory canopy in pure stands over upland streams. The expansion of Rhododendron in western North Carolina began in the early 1900s, during a period that coincided with the cessation of fire and grazing disturbance in the region (McGee and Smith 1967). The burning of forests in the southern Appalachians before the 20th century (Sharitz and others 1992) may have prevented the establishment of Rhododendron thickets in the area (Phillips and Murdy 1985). Logging operations in the early 20th century opened up the canopy dramatically and stimulated the establishment and growth of understory species. Subsequent opening of the forest canopy in the 1930s by the blight-induced decline of the American chestnut (Castanea dentata) has also been suggested as a factor in Rhododendron establishment (McGinty 1972). Vegetation analyses at Coweeta, over long periods as well as following severe drought, indicate that Rhododendron canopies can have a significant impact on hardwood regeneration (Clinton and others 1993). A long-term study found that the regeneration of some hardwood species (Quercus prinus and Q. alba) was significantly reduced in plots with high Rhododendron densities (Phillips and Murdy 1985).

Forest managers have considered the removal of near-stream Rhododendron thickets as a means of facilitating the regeneration of cove hardwood and to clear corridors in cove areas for wildlife movement. One potential problem with this strategy, however, is that the removal of near-stream Rhododendron thickets may decrease the nutrientuptake capacity of riparian vegetation. Day and McGinty (1975) found that, in contrast to three other common species (Q. prinus, Tsuga canadensis, Cornus florida), Rhododendron had the largest leaf biomass for WS 18 at Coweeta. Rhododendron leaf turnover time ranges from 4 to 7 years (Nilsen 1986). Although nutrient concentrations in Rhododendron leaves are generally lower than in deciduous leaves, the long-lived and abundant leaf mass of this species constitutes a significant nutrient storage reservoir in the riparian zone (Monk and others 1985). We hypothesized that Rhododendron might be a keystone species on this landscape at the interface between terrestrial and aquatic systemsthat is, that near-stream thickets would have an impact on organic matter processing in the riparian zone, element transport into streams, and stream ecosystem structure and function.

We conducted a manipulative experiment to determine the effect that the removal of streamside Rhododendron maximum L. would have on the export of dissolved organic carbon (DOC) and nutrients $\left(\mathrm{Na}^{+}, \mathrm{K}^{+}, \mathrm{Ca}^{2+}, \mathrm{Mg}^{2+}, \mathrm{NO}_{3}{ }^{-}-\mathrm{N}, \mathrm{NH}_{4}{ }^{+}-\mathrm{N}\right.$, $\left.\mathrm{SO}_{4}{ }^{2-}, \mathrm{PO}_{4}{ }^{3-}-\mathrm{P}\right)$ to a headwater stream in the southern Appalachian mountains. The experiment spanned periods of both extreme drought and high precipitation. A terrain-based hillslope hydrologic model was implemented to estimate water flux and nutrient export from these hillslopes at hourly intervals over the 6-year period of the experiment (Yeakley and others 1994). During the course of the experiment, windthrow and the uprooting of nine canopy dominant trees occurred on our untreated site during Hurricane Opal. As a result, our study became a contrast of the effects of two types of vegetation disturbance on the transport of riparian nutrients and dissolved organic carbon (DOC): (a) basal cutting of Rhododendron, and (b) the uprooting of canopy trees.

\section{METHODS}

\section{Site Description}

The Coweeta Hydrologic Laboratory, Otto, North Carolina, USA, is situated in the eastern part of the southern Appalachian Blue Ridge (latitude $35^{\circ} 03^{\prime} \mathrm{N}$, longitude $83^{\circ} 25^{\prime} \mathrm{W}$ ) (Hatcher 1988). Elevations in the Coweeta Basin range from 675 to $1592 \mathrm{~m}$, over a drainage area of 1626 ha. The soils of Coweeta consist of mostly Ultisols and Inceptisols underlain by a deep saprolite layer. Average weathering profile thickness (depth to bedrock) is about $7 \mathrm{~m}$ (Swank 1986). Saprolite is thickest at the drainage divides between the watersheds. On the slopes between the drainage divides, erosion and mass wasting keep saprolite thinner. Vegetation in the lower elevations at Coweeta consists of secondgrowth oak-hickory (Quercus-Carya) forest. Mean annual precipitation at the base climate station (CS 

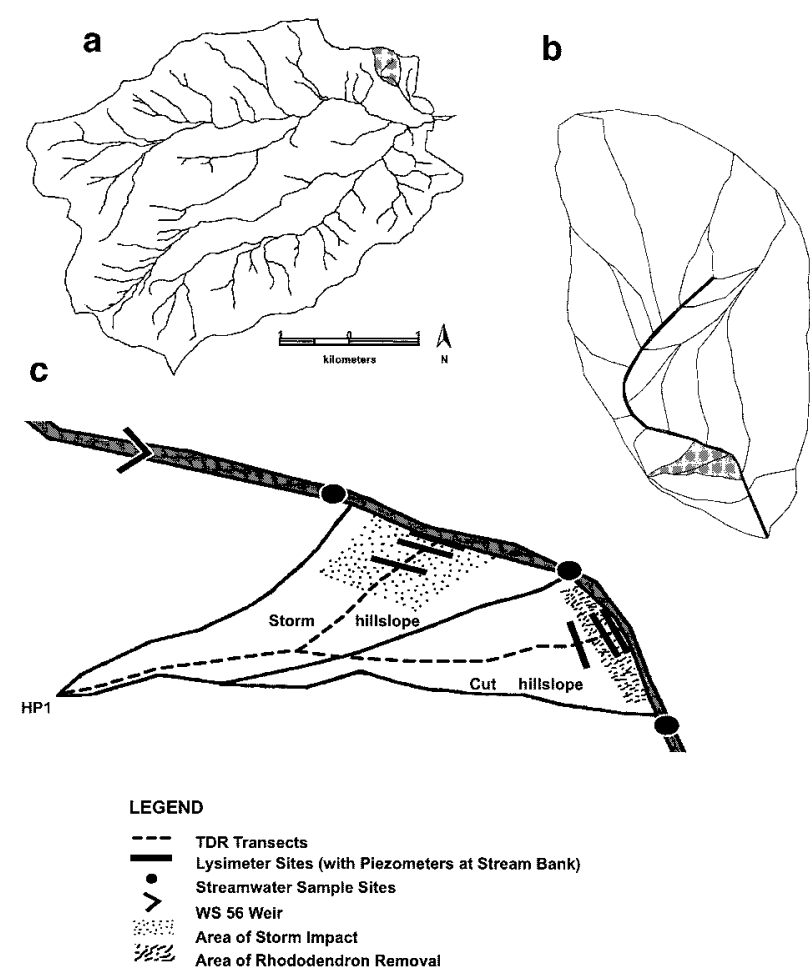

Figure 1. Schematic maps of the study site. (a) The Coweeta basin, including the stream network and basin divides. (b) The greater watershed, comprising both WS 56 and the experimental hillslopes downstream of the WS 56 weir; the hillslope planes delineated by the terrain analysis (TAPES-C) are shown. (c) The two experimental hillslopes, including high point 1 (HPl), the time domain reflectometry (TDR) transects, the lysimeter plots, the WS 56 weir upstream, the stream sampling locations, and the areas of vegetation disturbance.

$01)$ is $177 \mathrm{~cm}$. Rainfall varies seasonally from a monthly mean of $20.3 \mathrm{~cm}$ in March to a monthly mean of $11.2 \mathrm{~cm}$ in October (Swift and others 1988).

\section{Site Selection and Hydrologic Analysis}

The study site was located in a small watershed abutting the Coweeta Basin divide near the basin outlet. Field locations had treatment and reference hillslopes with similar parent material, aspect, topography, vegetation, and upslope hydrologic and nutrient contributions (Figure 1). To guide our field instrumentation, we used a contour-based analysis of terrain (Yeakley and others 1994). The TAPES-C (Topographic Analysis Programs for the Environmental Sciences-Contour) programs provided a contour-based method for partitioning the watersheds into natural units bounded by irregularly shaped polygons (Moore and Grayson 1991). Equi- potential (or contour) lines bound these polygons on two sides; streamlines, orthogonal to the contours, bound the other two sides. Streamlines are assumed to be no-flow boundaries; thus, groundwater flow is constrained to flow through a series of elements positioned along a natural gradient.

Two hillslope planes were selected (Figure 1), both starting at a common high point (HP1). These planes had an eastern aspect, with an average slope of 0.64 . The soil series on both hillslopes has been identified as Fannin, a fine-loamy, micaceous, mesic Typic Hapludult. The hillslope located further upstream was designated as the reference; the other hillslope was designated as the treatment, or "Cut," hillslope. After the hurricane impact, the reference, or uncut, hillslope was redesignated as the "Storm" hillslope. The areas of the hillslopes were 0.156 ha (Cut) and 0.211 ha (Storm); together, their area was $3.8 \%$ of the drainage area of WS 56 (9.68 ha) located further upstream (Figure 1).

After terrain analysis was completed using TAPES-C (Yeakley and others 1994), we implemented a physically based hillslope hydrology model to estimate water flux from each hillslope. The model (Institute of Hydrology Distributed Model v. 4 [IHDM4]) (Beven and others 1987) consisted of an aboveground component for climate processing and interception (Rutter and others 1975) and a subsurface hydrology component consisting of a finite element solution of a two-dimensional Richards equation. Along with spatially distributed terrain attributes, model parameters included canopy characteristics, soil hydraulic characteristics, and root characteristics. External variables that drive the model operated at an hourly time step and included rainfall, temperature, relative humidity, wind speed, and incident solar radiation. The model allows both unsaturated and saturated water flux within the hillslope, a variable saturation surface, and root water uptake for evapotranspiration (Beven and others 1987). The model is constrained so that hillslope water flow only reaches the stream via groundwater flux; that is, the model does not account for unsaturated flow from hillslope to stream. Calibration of the hydrologic model was performed following methods described elsewhere (Yeakley and others 2000) and used a month of wet antecedent conditions (April 1994) that included two significant storms. Modeled water flux was 38\% lower than the observed water flux for that month, although modeled hydrograph timing of the storm peaks was very close to the observed.

The model was validated using information from plot studies of soil moisture and groundwater depth 

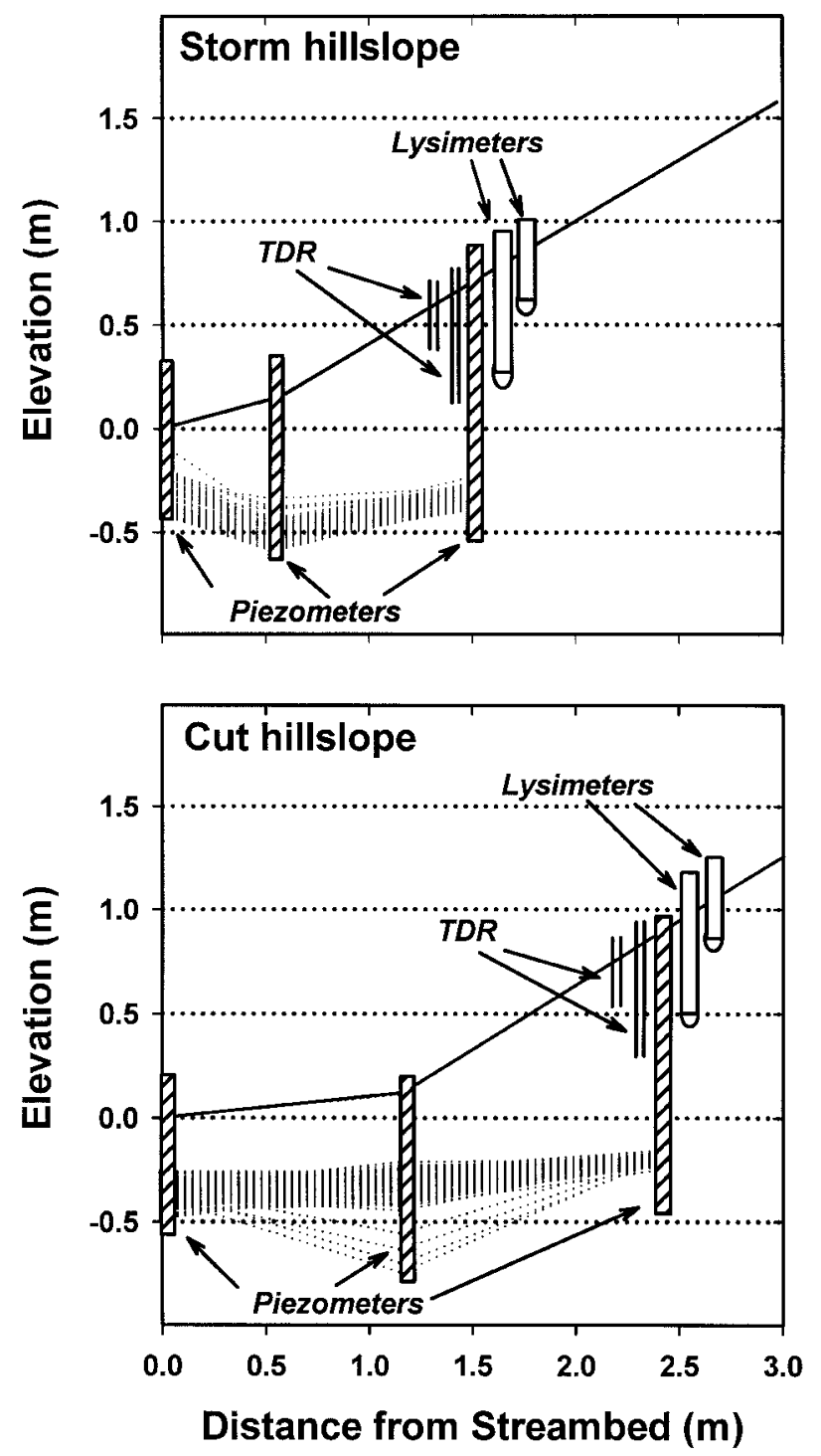

Figure 2. Profiles of near-stream instruments and mean groundwater level surface variation for the experimental hillslopes. Plots show the surveyed locations of the piezometers, lysimeters, and TDR rods for the first $3 \mathrm{~m}$ of each hillslope. The dotted vertical lines show the range of variation of the mean groundwater surface for the period of measurement (April 1995 to December 1998) for each hillslope.

(Figures 1 and 2), plus measurement of watershed stream discharge over storm and baseflow periods from the WS 56 weir (Figure 3). The range of modeled soil moisture was within $32 \%$ of observed values over the course of the study for either hillslope (Figure 3b). Modeled average soil moisture was within $9 \%$ of observed average values on the Storm hillslope, and it was within $1 \%$ of observed average values on the Cut hillslope. For streamflow, the model was validated by comparing water out- flow with measured streamflow from WS 56 (Figure 3c) for March-November 1995 and April-October 1996 (streamflow measurements at the weir were not taken during winter periods). This 15 month validation period included both low-flow summer periods and high-flow spring periods, as well as significant storm events such as Hurricane Opal (Figure 3a). Compared to measured streamflow from WS56, the total modeled water outflow from the experimental hillslopes for those two periods was 33\% higher on the Storm hillslope and $18 \%$ higher on the Cut hillslope. Generally, modeled hydrologic behavior was representative for these watersheds (Figure 3c). Simulated saturated surfaces were within $25 \mathrm{~cm}$ of the measured saturated surfaces on both hillslopes. Also, as is expected for Coweeta soils with high infiltration capacities, there was no overland flow in the simulations; hillslope water flux to stream occurred solely through the subsurface.

\section{Field and Laboratory Measurements}

On each experimental hillslope, the lower $15 \mathrm{~m}$ were instrumented with 24 porous-cup tension lysimeters (Hansen and Harris 1975) in the BA and B soil horizons for solute measurement. On each transect, three lysimeter plots were placed approximately 15, 5, and $2 \mathrm{~m}$ away from the edge of the streambed (Figures 1 and 2), with four replicates per plot at each of two depths $(20-25 \mathrm{~cm}$ for the BA horizon, 45-50 cm for the B horizon). Volumetric water content $\left(\mathrm{m}^{3} / \mathrm{m}^{3}\right)$ was estimated via time domain reflectometry (TDR) (Topp and others 1985; Yeakley and others 1998) at measurement points installed along the entire span of each transect, from stream to the high point (HP1). TDR plots were installed every $5 \mathrm{~m}$ through the lower $25 \mathrm{~m}$ of each transect, with three replicates per plot at each of two depths. TDR rods (3-mm-diameter stainless steel) were inserted vertically $5 \mathrm{~cm}$ apart for the $20-\mathrm{cm}$ and $50-\mathrm{cm}$ depths, corresponding to the BA and $\mathrm{B}$ soil horizons, respectively. Piezometers (1.25-cm inner diameter) were installed vertically at approximately $0,0.5-1.0$, and $1.5-2.5 \mathrm{~m}$ from the edge of the streambed on each transect (Figure $2)$. At each location, two replicates were installed, for a total of 12 piezometers on the experimental plots.

TDR and piezometer measurements were conducted biweekly; TDR measurements began in March 1993, and piezometer measurements began in April 1995. Lysimeters were evacuated to -0.03 $\mathrm{MPa}$, and weekly collections were made from March 1993 to December 1998. Approximately weekly, streamwater grab samples were collected 

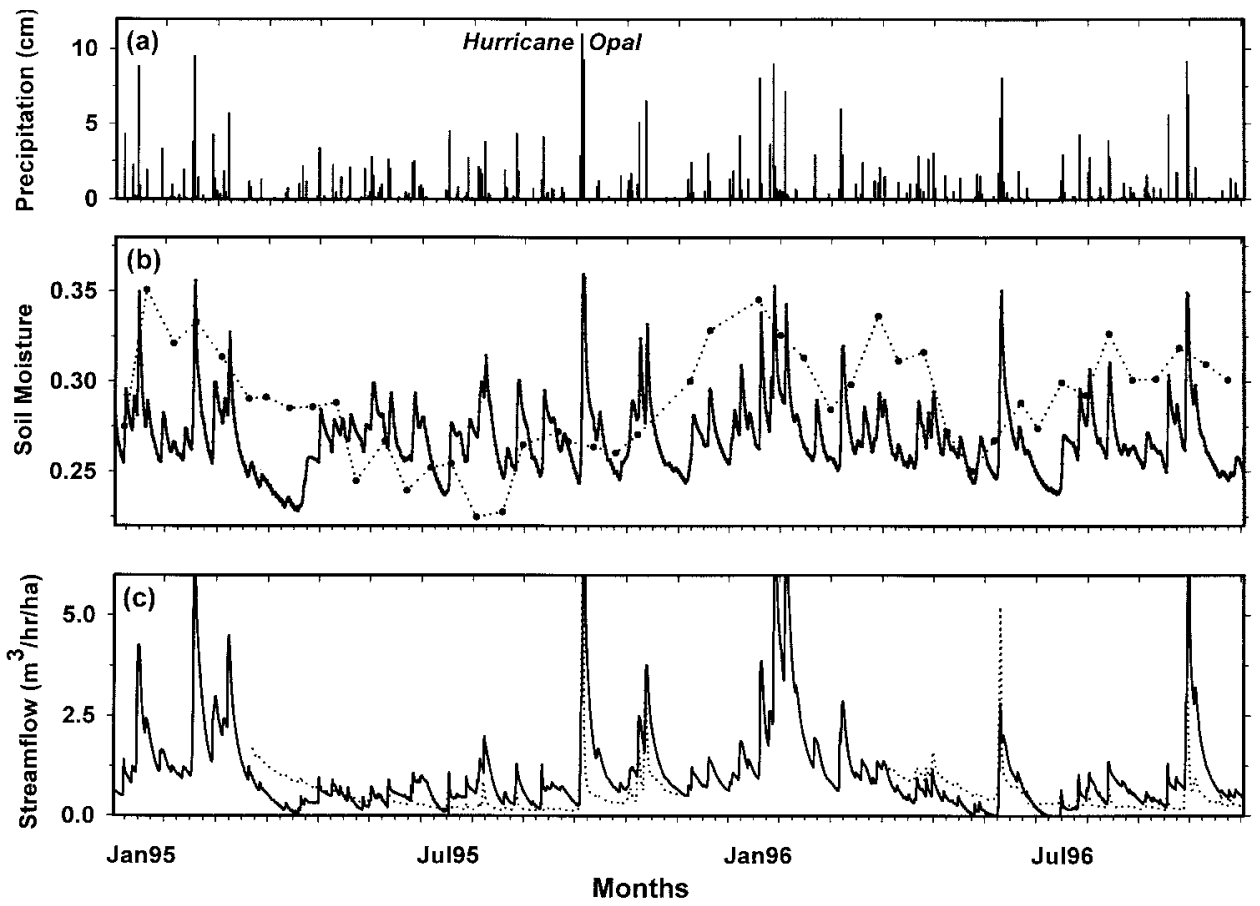

Figure 3. Rainfall, soil moisture, and hillslope runoff dynamics for the Storm hillslope. For the 22-month period bracketing Hurricane Opal, the panels show: a daily rainfall, b modeled and measured soil moisture, and c measured WS 56 streamflow and modeled hillslope water outflow. On b and c, the solid lines represent the modeled data, and the dotted lines represent the measured data. upstream at the WS 56 weir (Figure 1) beginning in January 1993. Further streamwater grab samples were collected beginning in April 1995, including upstream of the Storm hillslope and downstream of the Cut hillslope. In August 1997, an additional streamwater sample was collected between the hillslopes (Figure 1).

Water samples from stream, lysimeters, and piezometers were returned to the laboratory and refrigerated immediately; the weekly samples were composited monthly for analysis that followed within 7 days of compositing. For nutrient determinations, the samples were not filtered; prior studies of Coweeta water samples have shown negligible suspended concentrations (Vose and others 2002). Concentrations of $\mathrm{K}^{+}, \mathrm{Na}^{+}$, $\mathrm{Ca}^{2+}$, and $\mathrm{Mg}^{2+}$ were determined with a Perkin Elmer 2100 Atomic Absorption Spectrophotometer (Perkin Elmer, Norwalk, CT, USA). $\mathrm{PO}_{4}{ }^{3-}-\mathrm{P}$, $\mathrm{NO}_{3}{ }^{-}-\mathrm{N}, \mathrm{SO}_{4}{ }^{2-}$, and $\mathrm{Cl}^{-}$concentrations were measured with a Dionex Series 4500i Ion Chromatograph (Dionex, Sunnyvale, CA, USA). $\mathrm{NH}_{4}{ }^{+}$-N concentrations were determined colorimetrically with an Enviroflow 3700 (OI Analytical, College Station, TX, USA), and DOC concentrations were determined on filtered samples using a Model 700 TOC Analyzer with persulfate oxidation (OI Analytical). Measurement of $\mathrm{pH}$ was performed with an Orion digital $\mathrm{pH}$ meter (model 611; Orion Research, Beverly, MA, USA).

\section{Treatments}

On 29 August 1995, Rhododendron stems on the Cut hillslope were removed with chainsaw and shears in an area extending from the streambed to $10 \mathrm{~m}$ upslope and $30 \mathrm{~m}$ along the stream. The cut area included the 2-m and 5-m lysimeter and TDR plots and all piezometers. The upper 15-m lysimeter and TDR plot remained as an untreated area on the Cut hillslope (Figure 1). Soil water content and chemistry on the upper undisturbed area were used as the reference in the study. All slash was immediately removed, and soil disturbance was minimized. Sixty-five Rhododendron stems were cut. Using an allometric equation developed for Rhododendron at Coweeta, total biomass removed was estimated as $2.2 \mathrm{Mg}$, or $9.7 \mathrm{~kg} / \mathrm{m}^{2}$. Sixteen deciduous trees were left standing in the area of the cut. Total biomass was estimated as $7.2 \mathrm{Mg}$, or $22.5 \mathrm{~kg} / \mathrm{m}^{2}$, using an allometric equation for deciduous species at Coweeta (Martin and others 1998). Hence, $30 \%$ of the total woody biomass was removed. After cutting, the herbicide Roundup (Monsanto, Luling, LA, USA) was applied once to the top of cut stumps. No tests were conducted of the potential effects that this single herbicide application might have on soil microbial communities. Subsequent sprouts from cut stumps were clipped.

On 4-5 October 1995, Hurricane Opal struck the Coweeta Basin. The center of the storm track was $180 \mathrm{~km}$ west of the basin. National Oceanographic 


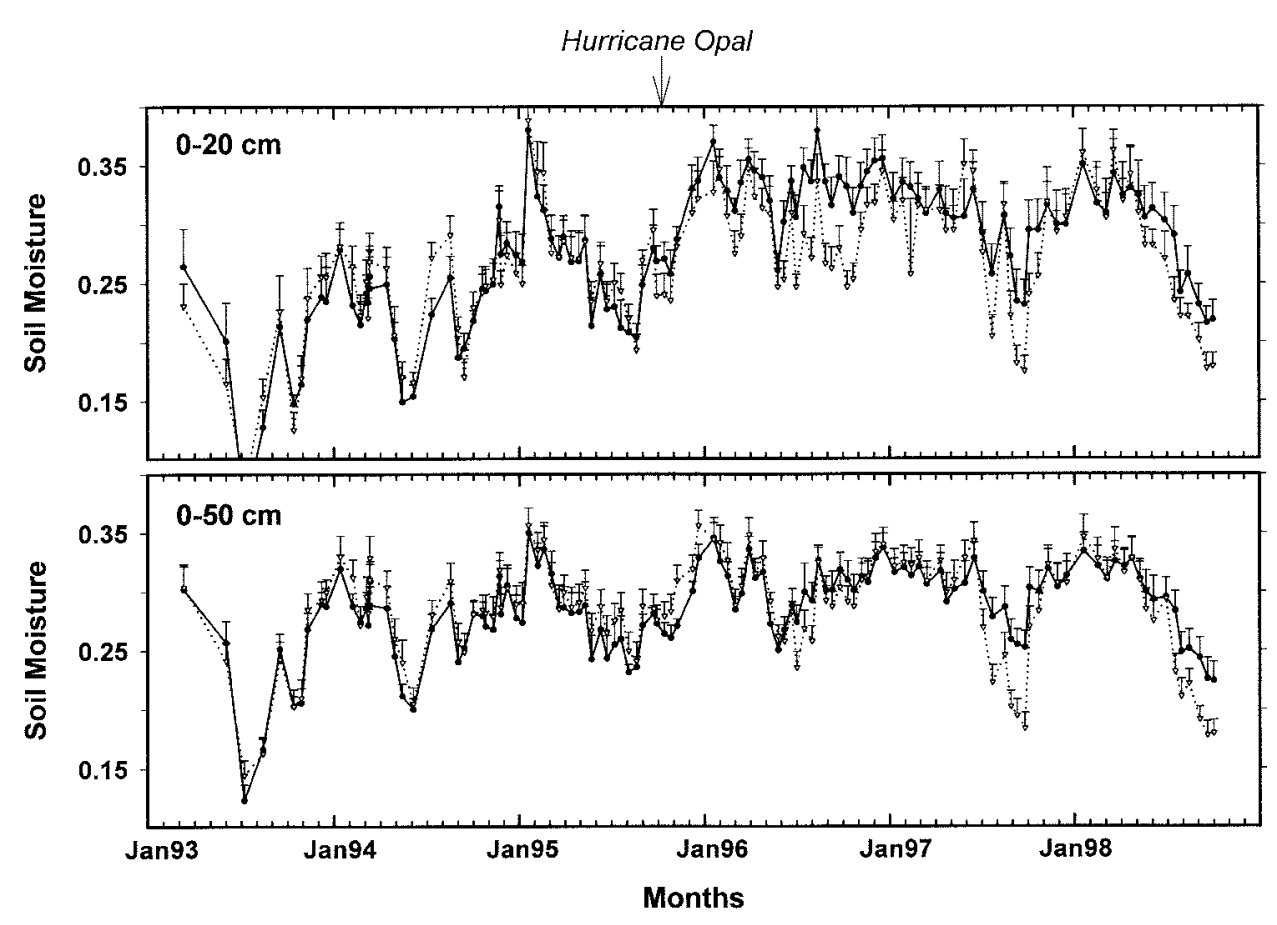

Figure 4. Soil moisture dynamics at $0-20 \mathrm{~cm}$ and $0-50 \mathrm{~cm}$ on the Cut and Storm hillslopes. The plots compare mean soil moisture, with error bars showing $1 \mathrm{SE}$, within $5 \mathrm{~m}$ of the stream at two different depths for the Cut hillslope $(\nabla)$ and the Storm hillslope $(\bullet)$.

and Atmospheric Administration (NOAA) stations in the Asheville, North Carolina, vicinity recorded wind gusts of up to $26 \mathrm{~m} \mathrm{~s}^{-1}$ at low elevations and up to $37 \mathrm{~m} \mathrm{~s}^{-1}$ at high elevations. Coweeta received $10.7 \mathrm{~cm}$ of rainfall during the $24 \mathrm{~h}$ prior to the storm and $8.9 \mathrm{~cm}$ of rain during the $24 \mathrm{~h}$ of the storm (Figure 3a). The storm caused uprooting of canopy trees throughout the Coweeta Basin, primarily on south-facing slopes. On the Storm hillslope, the lysimeters and TDR plots at $15 \mathrm{~m}$ from stream were destroyed, but the lysimeters downslope at $5 \mathrm{~m}$ and $2 \mathrm{~m}$ from stream remained intact. Nineteen deciduous trees ranging from 5.7 to 81.5 $\mathrm{cm}$ diameter at breast height $(\mathrm{DBH})$, including nine canopy trees (larger than $30 \mathrm{~cm} \mathrm{DBH}$ ), were uprooted by the storm, beginning approximately $25 \mathrm{~m}$ upslope and continuing down to the stream. The total biomass of the uprooted trees was estimated as $20.2 \mathrm{Mg}$, or $63 \mathrm{~kg} / \mathrm{m}^{2}$. Eleven trees remained standing in the area of the storm impact, estimated at $11.5 \mathrm{~kg} / \mathrm{m}^{2}$. Forty-one Rhododendron stems also remained alive in the impact area, with biomass estimated at $4.2 \mathrm{~kg} / \mathrm{m}^{2}$. Assuming the same Rhododendron density prior to storm impact as on the Cut hillslope, total Rhododendron downed by the storm was $5.5 \mathrm{~kg} / \mathrm{m}^{2}$. Overall, the storm removed $81 \%$, or $68.5 \mathrm{~kg} / \mathrm{m}^{2}$, of the total woody biomass in the impact area.

Basal cutting of riparian Rhododendron affected the 2-m and 5-m lysimeter plots on the Cut hillslope. The hurricane impact on the canopy trees also affected the 2-m and 5-m lysimeter plots on the Storm hillslope. The only area that remained unaffected was the $15-\mathrm{m}$ lysimeter plots above the Rhododendron cut (Figure 1); that lysimeter plot served as a reference for soilwater chemistry from both the lower Cut hillslope and the Storm hillslope.

\section{Data Analysis}

Statistical analysis for treatment effects was conducted using randomized intervention analysis (RIA) (Carpenter and others 1989). For soilwater, RIA was conducted for mean concentrations of DOC and every nutrient in both the BA and B horizons. The undisturbed lysimeter plot above the Rhododendron cut served as the reference for both the BA and B horizon samples (Figure 1). RIA was conducted for monthly samples for both growing seasons (May through October) and the entire period of the experiment. For groundwater, RIA was conducted for mean concentrations of every nutrient in the piezometers located at the lowest lysimeter plot (Figure 2), which contained water throughout the period of measurement. For groundwater, there was no undisturbed reference per se. RIA was conducted to determine the effect of hurricane impact on Storm hillslope groundwater nutrient concentrations using the groundwater values from the Cut hillslope as a reference. For streamwater, RIA was conducted comparing mean concentrations of nutrients upstream and down- 


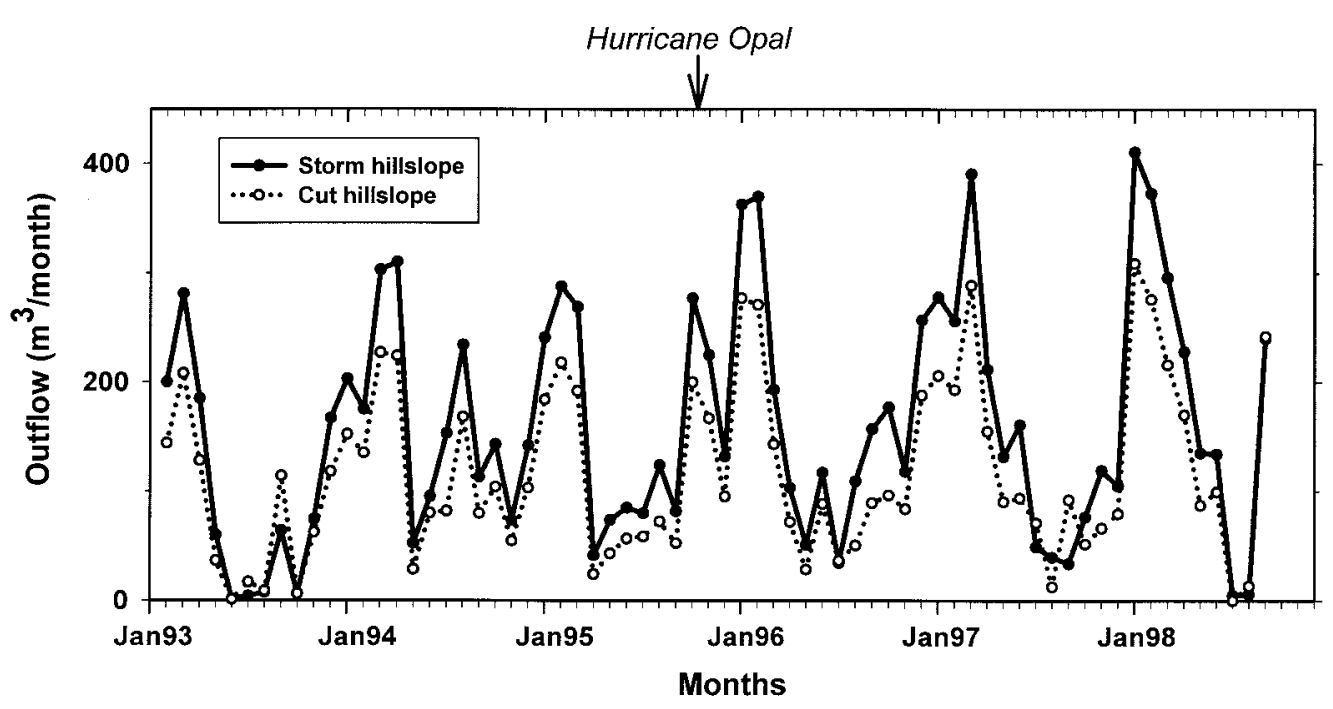

Figure 5. Simulated hillslope water outflow for the Cut and Storm hillslopes. Values represent monthly water outflow for each hillslope.

stream of the experimental hillslopes, before and after the hurricane impact.

To obtain estimates of hillslope nutrient flux, monthly mean nutrient concentrations in groundwater were multiplied by modeled water flux at hourly intervals for each hillslope. Flux estimates reported here assume that nutrient contributions to stream occur through groundwater flux only and that nutrient concentrations in groundwater were constant for a given month.

\section{RESUltS}

\section{Hydrologic Responses}

Over the period of the study (1993-98), there were four droughts and two extended wet periods (Figure 4). When compared with reference TDR plots from above the cut to the high point $(n=27$ plots per depth), soil moisture on the Storm hillslope increased in both soil depths $(0-20 \mathrm{~cm}$, $+30.9 \% ; 0-50 \mathrm{~cm},+6.1 \%)$. Although reference soil moisture also increased after the blowdown due to higher mean rainfall in the postimpact period, these increases on the Storm hillslope were significant (RIA, $P<0.01$ ). In contrast, soil moisture on the Cut hillslope showed no change in the $0-20-\mathrm{cm}$ depth and a significant decrease $(-3.3 \%)$ in the $0-50-\mathrm{cm}$ depth after cutting $(P<$ $0.05)$.

Regardless of climate variation or contrasting soil moisture variations after disturbance, groundwater depths did not vary more than $25 \mathrm{~cm}$ vertically on either hillslope for the entire period of measurement (Figure 2). The hydraulic gradient was larger on the Storm hillslope throughout the study. At all times, the depths of the phreatic surfaces remained at least $40 \mathrm{~cm}$ below the deepest porous lysimeter cup on either hillslope (Figure 2).

Higher rainfall amounts and lower evaporative demand in winter resulted in seasonal variation in modeled water flux from the hillslopes for the period from January 1993 to September 1998 (Figure 5). Water flux approached zero twice, during each of the dry summers of 1993 and 1998. Over the 5.75 -year period of the simulation, water flux was greater on the Storm hillslope $\left(10,690 \mathrm{~m}^{3}\right)$ than on the Cut hillslope $\left(7880 \mathrm{~m}^{3}\right)$. This $36 \%$ difference corresponded closely to the $35 \%$ difference in plane area between the two hillslopes. Modeled water flux between hillslopes was not significantly different before or after disturbance during the period of the study (RIA, $P=0.64$ ).

\section{Soilwater Nutrient and DOC Responses}

Long-term mean nutrient concentrations in soilwater on both hillslopes showed significant changes following disturbance. On the Cut hillslope, DOC, $\mathrm{SO}_{4}{ }^{2-}$, and base cation concentrations all decreased in both the BA and B horizons (Figure 6a and Tables 1 and 2). A statistically significant increase in $\mathrm{NO}_{3}{ }^{-}-\mathrm{N}$ concentrations in the $\mathrm{B}$ horizon was also observed on the Cut hillslope, with mean $\mathrm{NO}_{3}{ }^{-}-\mathrm{N}$ concentration tripling following the vegetation removal. No significant change in $\mathrm{pH}$ was observed on the Cut hillslope.

Nutrient responses were much greater on the Storm hillslope than on the Cut hillslope in both the $\mathrm{BA}$ and B horizons (Figure $6 \mathrm{~b}$ and Tables 1 and 2). On the Storm hillslope in the B horizon, DOC and $\mathrm{SO}_{4}{ }^{2-}$ concentrations decreased, whereas $\mathrm{H}^{+}$ion 

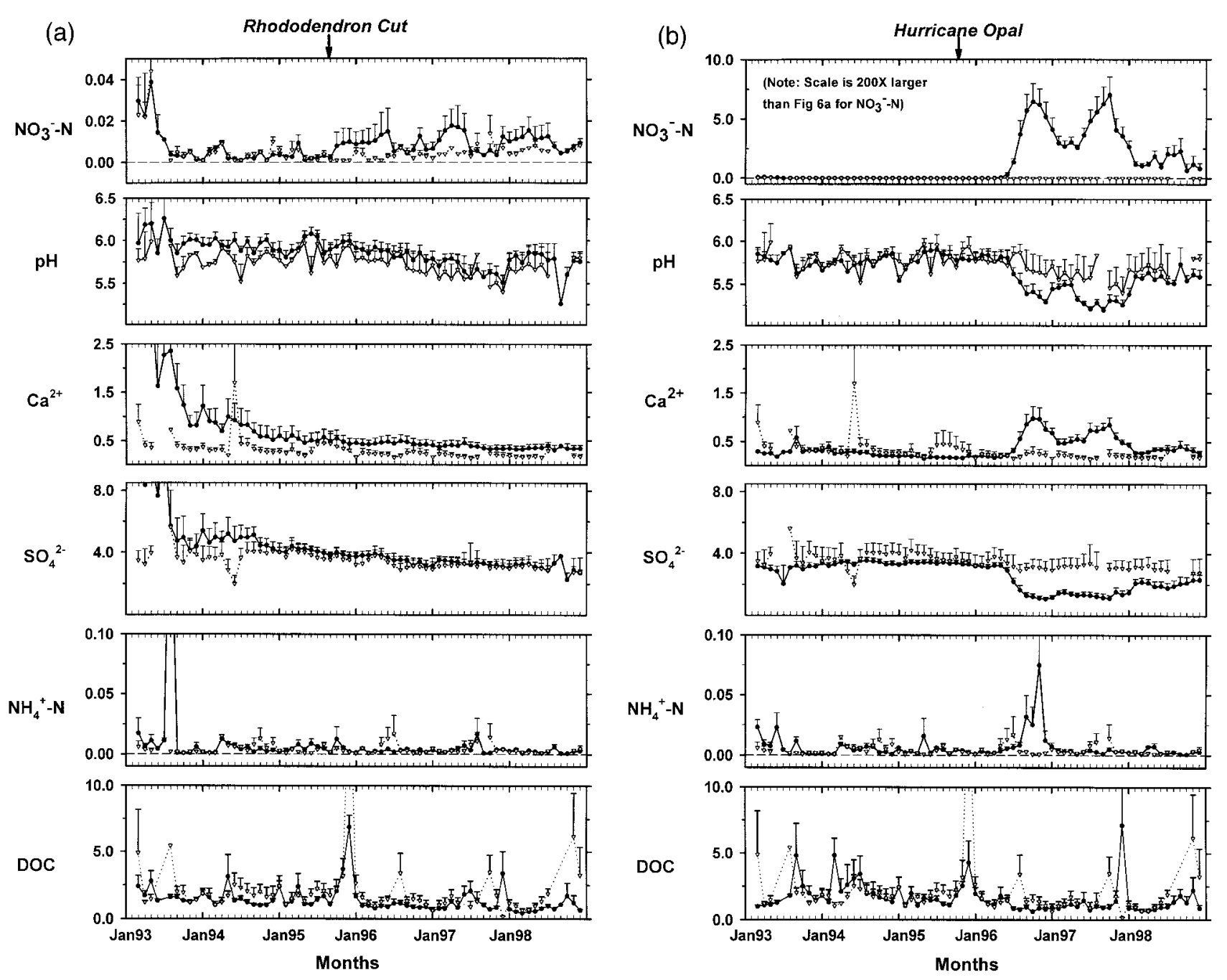

Figure 6. Soilwater nutrient dynamics in the B horizon before and after disturbance. On all plots, the mean of the monthly lysimeter sample concentrations $(\nabla)$ in the B horizon from a reference plot above the cut area is compared with the mean of monthly lysimeter sample concentrations $(-)$ in the B horizon in the area $0-5 \mathrm{~m}$ from stream for (a) the Cut hillslope and (b) the Storm hillslope. Error bars show $1 \mathrm{SE}$; units for all nutrients and DOC are in $\mathrm{mg} / \mathrm{L}$.

concentration increased (Figure $6 \mathrm{~b}$ and Table 2). In both horizons on the Storm hillslope, base cation concentrations and $\mathrm{NO}_{3}{ }^{-} \mathrm{N}$ concentrations increased greatly (Figure $6 \mathrm{~b}$ and Tables 1 and 2). Randomized intervention analysis results for growing season data (May-September) were consistent with RIA of the long-term mean results. $\mathrm{NO}_{3}{ }^{-}-\mathrm{N}$ concentrations in the soilwater remained elevated for at least 3 years following the storm disturbance. Soilwater $\mathrm{NO}_{3}{ }^{-}-\mathrm{N}$ concentration increases began in the growing season following the storm disturbance and averaged approximately 500-fold greater than predisturbance $\mathrm{NO}_{3}{ }^{-}-\mathrm{N}$ concentration levels during the 3 years following the storm (Figure $6 \mathrm{~b}$ and Tables 1 and 2).

\section{Groundwater and Streamwater Nutrient} Responses

Near-stream groundwater nutrient concentrations did not vary on the Cut hillslope after Rhododendron cutting. In contrast, near-stream groundwater nutrient concentrations on the Storm hillslope had changes in $\mathrm{H}^{+}, \mathrm{SO}_{4}{ }^{2-}, \mathrm{NO}_{3}{ }^{-}-\mathrm{N}$, and base cations (Table 3). Notably, the Storm hillslope's nearstream groundwater showed more than a doubling of $\mathrm{H}^{+}$and a fourfold increase of $\mathrm{NO}_{3}{ }^{-}-\mathrm{N}$ concentrations after Hurricane Opal. Preimpact groundwater data were recorded over a shorter period $(6$ months) than soilwater data in this study, yet preimpact groundwater $\mathrm{NO}_{3}{ }^{-}-\mathrm{N}$ concentrations were 
Table 1. Soil Water Chemistry in the BA Horizon

\begin{tabular}{|c|c|c|c|c|c|c|}
\hline \multirow{2}{*}{$\begin{array}{l}\text { Means } \\
(\mathrm{mg} / \mathrm{L})\end{array}$} & \multicolumn{3}{|c|}{ Preimpact ${ }^{a}$} & \multicolumn{3}{|c|}{ Postimpact ${ }^{b}$} \\
\hline & Reference & Veg Cut & Storm & Reference & Veg Cut & Storm \\
\hline $\mathrm{H}^{+}$ & $4.94 \mathrm{E}-6$ & $7.34 \mathrm{E}-7$ & $1.46 \mathrm{E}-6$ & $3.22 \mathrm{E}-6$ & $1.27 \mathrm{E}-6$ & $2.15 \mathrm{E}-6$ \\
\hline $\mathrm{NO}_{3}{ }^{-}-\mathrm{N}$ & 0.008 & 0.004 & 0.005 & 0.011 & 0.005 & $2.55^{d}$ \\
\hline $\mathrm{NH}^{4+}-\mathrm{N}$ & 0.017 & 0.007 & 0.013 & 0.005 & 0.005 & $0.013^{c}$ \\
\hline $\mathrm{PO}_{4}{ }^{3-}-\mathrm{P}$ & 0.004 & 0.012 & 0.005 & 0.003 & $0.006^{d}$ & $0.015^{d}$ \\
\hline $\mathrm{SO}_{4}^{2-}$ & 4.14 & 5.58 & 3.60 & 2.93 & $3.15^{d}$ & 2.54 \\
\hline $\mathrm{Cl}^{-}$ & 0.782 & 0.919 & 0.580 & 1.04 & 0.804 & 0.590 \\
\hline $\mathrm{Na}^{+}$ & 0.420 & 0.357 & 0.321 & 0.320 & 0.245 & 0.272 \\
\hline $\mathrm{K}^{+}$ & 2.36 & 0.840 & 0.518 & 1.37 & 0.438 & $0.614^{d}$ \\
\hline $\mathrm{Ca}^{2+}$ & 1.35 & 1.89 & 0.682 & 0.625 & $0.951^{d}$ & $0.785^{d}$ \\
\hline $\mathrm{Mg}^{2+}$ & 1.02 & 1.04 & 1.33 & 0.652 & $0.618^{c}$ & $2.27^{d}$ \\
\hline DOC & 20.1 & 3.99 & 8.97 & 9.32 & $2.69^{c}$ & 4.26 \\
\hline \multicolumn{7}{|c|}{$\begin{array}{l}\text { Mean values were compared for pre-and postimpact for both the Vegetation Cut (29 August 1995) and the Storm Impact (4-5 October 1995). Randomized intervention analysis } \\
\text { (RIA) was used to determine significant differences in soil water nutrients and dissolved organic carbon (DOC). Comparisons for all RIA were made with a reference lysimeter } \\
\text { site located above the Rhododendron removal area on the Cut hillslope. } \\
\text { aMonthly time series from September } 1993 \text { to August } 1995 \\
\text { bonthly time series from October } 1995 \text { to December } 1998 \\
\text { Monnificant at } P<0.05 \\
\text { Significant at } P<0.01\end{array}$} \\
\hline
\end{tabular}

Table 2. Soil Water Chemistry in the B Horizon

\begin{tabular}{|c|c|c|c|c|c|c|}
\hline \multirow{2}{*}{$\begin{array}{l}\text { Means } \\
(\mathrm{mg} / \mathrm{L})\end{array}$} & \multicolumn{3}{|c|}{ Preimpact ${ }^{a}$} & \multicolumn{3}{|c|}{ Postimpact $^{b}$} \\
\hline & Reference & Veg Cut & Storm & Reference & Veg Cut & Storm \\
\hline $\mathrm{H}^{+}$ & $1.74 \mathrm{E}-06$ & $1.15 \mathrm{E}-06$ & $1.79 \mathrm{E}-06$ & $2.12 \mathrm{E}-06$ & $1.66 \mathrm{E}-06$ & $3.25 \mathrm{E}-06^{\mathrm{C}}$ \\
\hline $\mathrm{NO}_{3}{ }^{-}-\mathrm{N}$ & 0.004 & 0.003 & 0.005 & 0.005 & $0.010^{d}$ & $2.38^{d}$ \\
\hline $\mathrm{NH}^{4+}-\mathrm{N}$ & 0.004 & 0.004 & 0.004 & 0.004 & 0.004 & 0.007 \\
\hline $\mathrm{PO}_{4}{ }^{3-}-\mathrm{P}$ & 0.004 & 0.002 & 0.003 & 0.002 & 0.023 & 0.003 \\
\hline $\mathrm{SO}_{4}^{2-}$ & 3.73 & 4.55 & 3.34 & 3.20 & $3.37^{d}$ & $1.99^{d}$ \\
\hline $\mathrm{Cl}^{-}$ & 0.904 & 0.843 & 0.593 & 0.938 & $0.528^{d}$ & 0.575 \\
\hline $\mathrm{Na}^{+}$ & 0.335 & 0.493 & 0.301 & 0.260 & $0.256^{c}$ & 0.285 \\
\hline $\mathrm{K}^{+}$ & 0.861 & 0.314 & 0.384 & 0.865 & 0.272 & 0.644 \\
\hline $\mathrm{Ca}^{2+}$ & 0.374 & 0.765 & 0.258 & 0.216 & $0.402^{d}$ & $0.449^{d}$ \\
\hline $\mathrm{Mg}^{2+}$ & 0.969 & 1.11 & 0.916 & 0.751 & $0.802^{d}$ & $1.98^{d}$ \\
\hline DOC & 1.76 & 1.46 & 2.10 & 2.48 & $1.28^{c}$ & $1.40^{d}$ \\
\hline
\end{tabular}

Mean values were compared for pre-and postimpact for both the Vegetation Cut (29 August 1995) and the Storm Impact (4-5 October 1995). Randomized intervention analysis (RIA) was used to determine significant differences in soil water nutrients and dissolved organic carbon (DOC). Comparisons for all RIA were made with a reference lysimeter site located above the Rhododendron removal area on the Cut hillslope.

${ }^{a}$ Monthly time series from September 1993 to August 1995

${ }^{b}$ Monthly time series from October 1995 to December 1998

Significant at $P<0.05$

Significant at $P<0.01$

consistent with prior studies. For example, a storm study of $\mathrm{NO}_{3}{ }^{-}-\mathrm{N}$ in 12 streambed wells in WS 56 over a storm period during 7-10 March 1994 showed $\mathrm{NO}_{3}{ }^{-}$-N concentrations ranging from 0.009 to $0.064 \mathrm{mg} / \mathrm{L}$ (J. R. Webster and J. A. Yeakley unpublished). Further, RIA showed that differences between groundwater $\mathrm{NO}_{3}{ }^{-}-\mathrm{N}$ concentrations on the Storm hillslope before and after Hurricane Opal were quite significant $(P<0.01)$.
These changes in nutrient concentration corresponded to changes in modeled elemental flux before and after disturbance. On the Storm hillslope, during the 3 years following disturbance, mean $\mathrm{NO}_{3}{ }^{-}$-N flux increased fivefold (Figure 7). Due to higher water outflow from these hillslopes during high precipitation and low evapotranspiration periods of the winter months, modeled nutrient fluxes were higher during winter. These model results 
Table 3. Ground Water Chemistry in the Riparian Zone

\begin{tabular}{|c|c|c|c|c|}
\hline \multirow{2}{*}{$\begin{array}{l}\text { Means } \\
(\mathrm{mg} / \mathrm{L})\end{array}$} & \multicolumn{2}{|c|}{ Preimpact $^{a}$} & \multicolumn{2}{|c|}{ Postimpact ${ }^{b}$} \\
\hline & Veg Cut & Storm & Veg Cut & Storm \\
\hline $\mathrm{H}^{+}$ & 4.91E-07 & $4.40 \mathrm{E}-07$ & $5.94 \mathrm{E}-07$ & $1.12 \mathrm{E}-06$ \\
\hline $\mathrm{NO}_{3}{ }^{-}-\mathrm{N}$ & 0.042 & 0.057 & 0.047 & $0.245^{d}$ \\
\hline $\mathrm{NH}^{4+}-\mathrm{N}$ & 0.089 & 0.156 & 0.049 & 0.059 \\
\hline $\mathrm{PO}_{4}{ }^{3-}-\mathrm{P}$ & 0.002 & 0.020 & 0.003 & 0.003 \\
\hline $\mathrm{SO}_{4}^{2-}$ & 0.496 & 1.16 & 0.487 & $0.759^{d}$ \\
\hline $\mathrm{Cl}^{-}$ & 0.851 & 0.701 & 0.645 & 0.591 \\
\hline $\mathrm{Na}^{+}$ & 1.04 & 1.13 & 0.842 & 0.796 \\
\hline $\mathrm{K}^{+}$ & 0.537 & 1.08 & 0.440 & 1.24 \\
\hline $\mathrm{Ca}^{2+}$ & 1.15 & 0.506 & 0.565 & $0.606^{c}$ \\
\hline $\mathrm{Mg}^{2+}$ & 0.544 & 0.585 & 0.341 & $0.600^{c}$ \\
\hline \multicolumn{5}{|c|}{$\begin{array}{l}\text { Mean values were compared for pre- and postimpact for the Storm Impact (4-5 October 1995). Randomized intervention analysis (RIA) was used to determine significant } \\
\text { differences in groundwater nutrients. Comparisons for all RIA were made using groundwater nutrient concentrations on the Cut hillslope as a reference. } \\
\text { a Monthly time series from April } 1995 \text { to October } 1995 \\
\text { bonthly time series from November } 1995 \text { to December } 1998 \\
\text { 'Mignificant at } P<0.05 \\
\text { dignificant at } P<0.01\end{array}$} \\
\hline
\end{tabular}

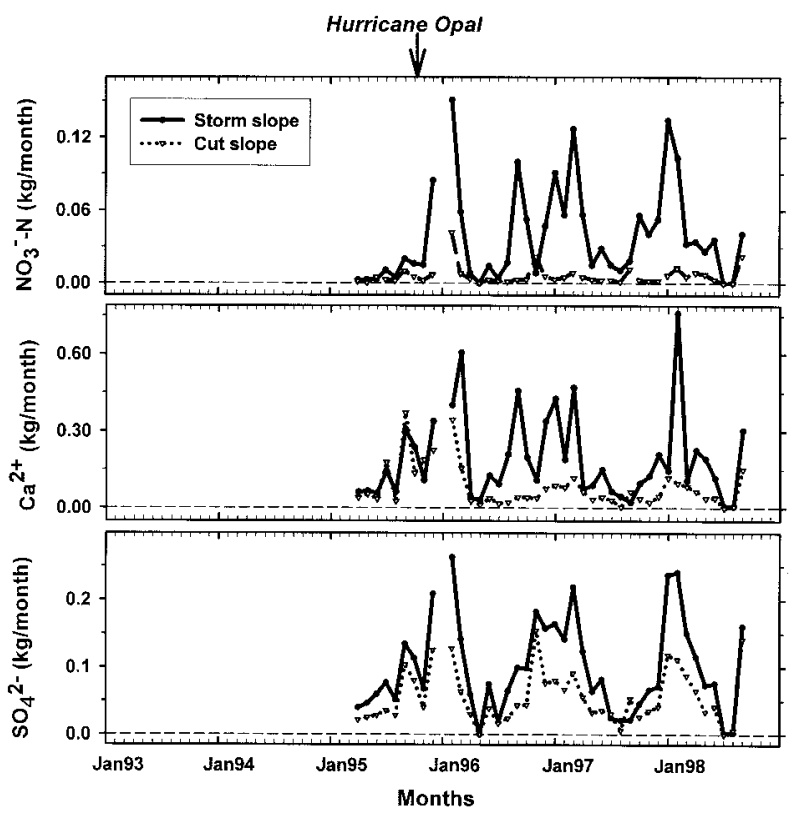

Figure 7. Modeled nutrient export from both the Storm hillslope $(\bullet)$ and the Cut hillslope $(\nabla)$.

account for nutrient flux to stream via groundwater flow only and show relative flux differences from the hillslopes after contrasting impacts (Figure 7).

Following the uprooting of canopy trees from Hurricane Opal, streamwater concentrations of $\mathrm{NO}_{3}{ }^{-}$-N doubled (Figure 8 and Table 4). Although the postimpact streamwater data were taken from below both hillslopes, the lack of groundwater nutrient response on the Cut hillslope combined with the significant increase in groundwater $\mathrm{NO}_{3}{ }^{-} \mathrm{-N}$ on the Storm hillslope clearly implicates the Storm impact as the cause of the streamwater $\mathrm{NO}_{3}{ }^{-}-\mathrm{N}$ increase. Streamwater nutrient concentrations taken between slopes (Figure 1) from August 1997 to December 1998 were indistinguishable from streamwater nutrient concentration data recorded for that same period below the Cut hillslope (Figure 8 ), isolating the streamwater chemistry response to the Storm hillslope. No other significant changes in streamwater $\mathrm{pH}$ or nutrients were observed. Increases in $\mathrm{NO}_{3}{ }^{-}-\mathrm{N}$ concentration following the storm disturbance were observed in all hydrologic components: soilwater, groundwater, and streamwater (Figure 8). These increases were persistent and significant for the entire 3-year postdisturbance period.

\section{DISCUSSION}

\section{Rhododendron Removal}

Nutrient concentrations in soilwater on the Rhododendron Cut hillslope showed changes in concentrations of several nutrients and of DOC; however, these changes did not reach the groundwater or the streamwater. No disruptions of the soil or Rhododendron root systems occurred during the understory removal. In a concurrent study on the site, microbial biomass measured quarterly from March 1994 to September 1997 on the Cut hillslope showed no major changes, ranging between 0.7 and $1.4 \mathrm{mg} \mathrm{C} \mathrm{g}^{-1}$ dry soil in the top $5 \mathrm{~cm}$ of soil and between 0.5 and $0.8 \mathrm{mg} \mathrm{C}^{-1}$ dry soil at a depth of 5-10 cm (Wright and Coleman 2002). In 

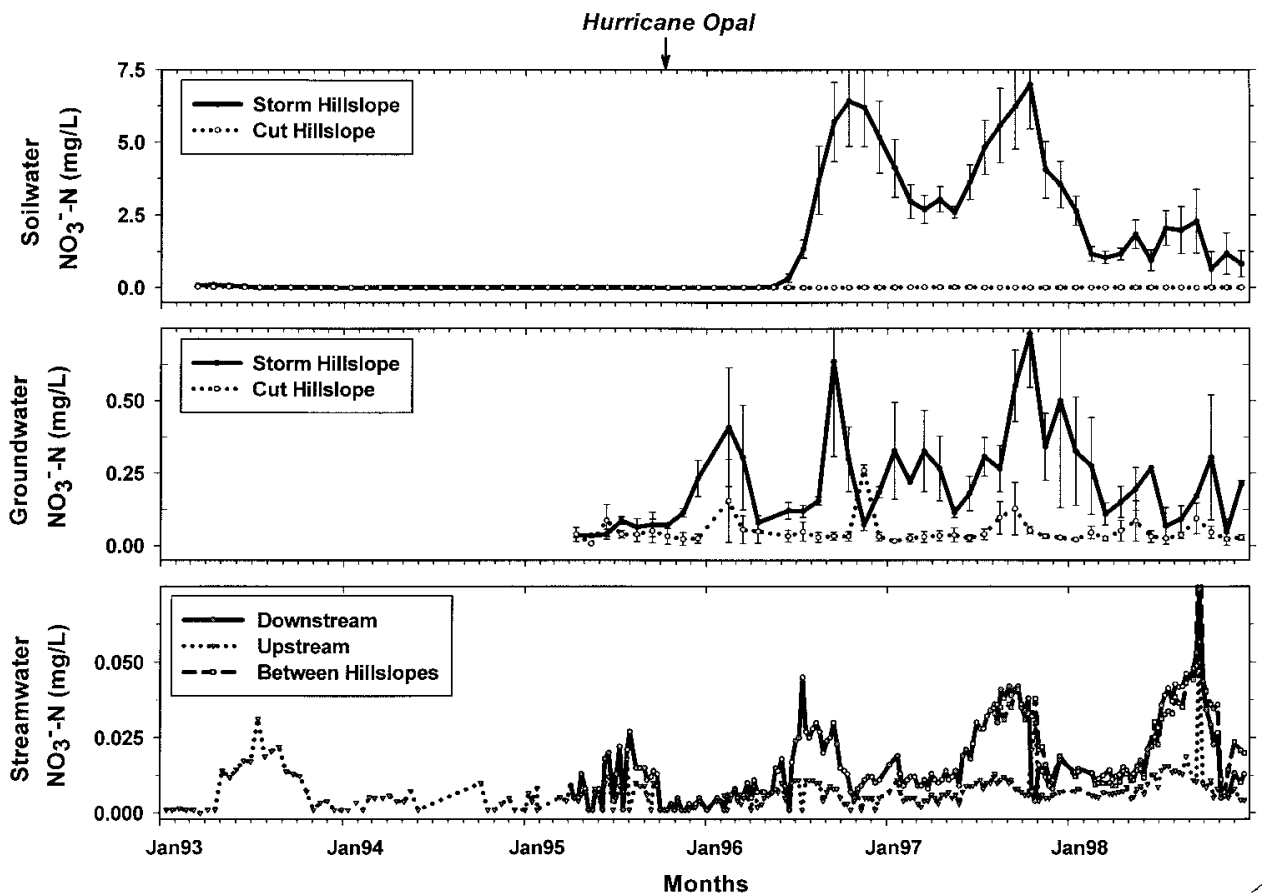

Figure 8. Mean $\mathrm{NO}_{3}{ }^{-}-\mathrm{N}$ concentrations in soilwater, groundwater, and streamwater over the period of the study. Soilwater samples were taken from the B horizon lysimeters in the area $0-5 \mathrm{~m}$ from stream. Groundwater samples were taken from piezometers located at the lowest lysimeter site on each hillslope. Streamwater samples upstream were taken from the WS 56 weir from January 1993 to March 1995, and then from above both hillslopes from April 1995 to December 1998. Streamwater samples downstream of the hillslopes were taken from April 1995 to December 1998. Streamwater samples between hillslopes were taken from August 1997 to December 1998.

Table 4. Streamwater Chemistry Upstream and Downstream of the Experimental Hillslopes

\begin{tabular}{lllll}
\hline \multirow{2}{*}{$\begin{array}{l}\text { Means } \\
(\mathrm{mg} / \mathrm{L})\end{array}$} & \multicolumn{2}{c}{ Preimpact $^{a}$} & \multicolumn{2}{c}{ Postimpact $^{b}$} \\
\cline { 2 - 3 } & Upstream & Downstream & Upstream & Downstream \\
\hline $\mathrm{H}^{+}$ & $1.84 \mathrm{E}-07$ & $2.32 \mathrm{E}-07$ & $2.73 \mathrm{E}-07$ & $3.67 \mathrm{E}-07$ \\
$\mathrm{NO}{ }^{-}{ }^{-}-\mathrm{N}$ & 0.006 & 0.010 & 0.007 & $0.018^{c}$ \\
$\mathrm{NH}^{4+}-\mathrm{N}$ & 0.002 & 0.002 & 0.003 & 0.003 \\
$\mathrm{PO}_{4}{ }^{3-}-\mathrm{P}$ & 0.001 & 0.001 & 0.003 & 0.004 \\
$\mathrm{SO}_{4}{ }^{2-}$ & 0.404 & 0.475 & 0.432 & 0.483 \\
$\mathrm{Cl}^{-}$ & 0.641 & 0.655 & 0.627 & 0.619 \\
$\mathrm{Na}^{+}$ & 0.855 & 0.876 & 0.798 & 0.811 \\
$\mathrm{~K}^{+}$ & 0.446 & 0.460 & 0.413 & 0.429 \\
$\mathrm{Ca}^{2+}$ & 0.532 & 0.563 & 0.539 & 0.508 \\
$\mathrm{Mg}^{2+}$ & 0.396 & 0.399 & 0.374 & 0.366
\end{tabular}

Mean values were compared for pre- and postimpact for both above and below the experimental hillslopes. Randomized intervention analysis (RIA) was used to determine significant differences in streamwater nutrients. Comparisons for all RIA were made using streamwater nutrient concentrations upstream of both hillslopes as a reference. ${ }_{b}$ Monthly time series from April 1995 to October 1995

Monthly time series from November 1995 to December 1998

Significant at $P<0.01$

situ net $\mathrm{N}$ mineralization increased significantly in only one month (September 1996) following the cutting (Wright and Coleman 2002).

Base cations decreased rather than responding with an increase, as has been observed when significant nitrification occurs following vegetation disturbance (Likens and others 1970). The increases observed in soilwater $\mathrm{NO}_{3}{ }^{-}-\mathrm{N}$ concentrations after Rhododendron cutting, although statistically significant, were not sufficient to lower $\mathrm{pH}$ or to increase base cation soilwater 
concentrations. Observed decreases in DOC concentration are consistent with declines in streamwater DOC observed after clear-cutting an entire watershed (Meyer and Tate 1983). These decreases may have been a consequence of reduced root exudates and leachable organic matter in the litter layer, although no significant changes in soil carbon were found (Wright and Coleman 2002).

\section{Uprooting of Canopy Vegetation}

In contrast to the Cut hillslope, soilwater nutrient concentrations on the Storm hillslope increased markedly beginning in the growing season (spring 1996) following the hurricane. Net $\mathrm{N}$ mineralization rates increased significantly on the Storm hillslope during the growing season that followed the hurricane impact (Wright and Coleman 2002). The likely reason for these growing-season responses was an increase in soil temperature, resulting in ammonification increases. Increased ammonification likely resulted in increased nitrification, which generated acidity by liberating protons during the oxidation of ammonium (Vitousek and others 1982). Soilwater $\mathrm{pH}$ on the Storm hillslope decreased significantly in both horizons. Increased acidity can cause the increased mobilization of cations, which are removed from cation exchange sites in favor of hydrogen ions (Likens and others 1970). In our study, $\mathrm{Ca}^{2+}$ and $\mathrm{Mg}^{2+}$ increased in the soilwater of both horizons and $\mathrm{K}^{+}$increased in the BA horizon following the uprooting of canopy vegetation during the hurricane. $\mathrm{SO}_{4}{ }^{2-}$ decreases in the $\mathrm{B}$ horizon may have been a result of increased soil anion adsorption capacity with increased acidity (Mitchell and others 1989) and/or accelerated microbial transformation of inorganic $S$ to organic $S$ forms (Fitzgerald and others 1982). Similar effects have been observed after prescribed harvests at the whole-watershed scale (Nodvin and others 1988; Swank 1988).

The soilwater $\mathrm{SO}_{4}{ }^{2-}$ decrease observed on the Storm hillslope following the storm impact was not large enough to affect a change in groundwater $\mathrm{SO}_{4}{ }^{2-}$ concentrations. $\mathrm{NO}_{3}{ }^{-}-\mathrm{N}$, in contrast, was exported to both groundwater and streamwater from the Storm hillslope at significantly higher rates following Hurricane Opal (Figure 8). Elevated $\mathrm{NO}_{3}{ }^{-}-\mathrm{N}$ streamwater concentrations have also been observed following canopy tree blowdown in the higher elevation WS 34 at Coweeta (Swank and Vose 1997). Hurricane impact caused a similar effect in a tropical forest. $\mathrm{NO}_{3}{ }^{-}-\mathrm{N}$ and base cations were found to have increased in groundwater at the Luquillo Experimental Forest for several years fol- lowing Hurricane Hugo (McDowell and others 1996).

On the Storm hillslope in our study, $\mathrm{NO}_{3}{ }^{-}-\mathrm{N}$ concentrations dropped by more than two orders of magnitude from soilwater to groundwater and again by a factor of two or more from groundwater to streamwater. This reduction of $\mathrm{NO}_{3}{ }^{-}-\mathrm{N}$ concentrations from soilwater to groundwater to streamwater was probably due to one or both of two factors: denitrification in the riparian zone, a process shown to be important in other Coweeta watersheds (Davidson and Swank 1987, 1990), and the dilution of $\mathrm{NO}_{3}{ }^{-}-\mathrm{N}$ as soilwater mixed into larger groundwater and streamwater volumes.

\section{Controls over $\mathrm{NO}_{3}{ }^{-}-\mathrm{N}$ Export}

Most studies of control over nutrients in riparian zones have focused on lowland agricultural or mixed forest/agricultural watersheds, with shallow slopes and periodically saturated surface soils (Peterjohn and Correll 1984; Hedin and others 1998). Although a few studies have been conducted in upland riparian areas (see, for example, Mulholland and Hill 1997), generally there have not been many studies in steeply sloped, headwater riparian areas where the saturated surface remains below the soil surface (Figure 2), leaving near-stream topsoil in a predominantly aerobic state. Results from our study suggest that nutrient uptake by vegetation exerts a key control over nutrient export at riparian interfaces in such upland headwater forests.

One hypothesis concerning nutrient cycling in forest ecosystems is that the root-soil connection may form a critical link in controlling $\mathrm{NO}_{3}{ }^{-}-\mathrm{N}$ losses (Aber and others 1998). Our results support that hypothesis. Disruption of the root-soil connection on the Storm hillslope likely resulted both in a decrease of nutrient uptake by tree vegetation, as well as a disruption of soil microbial nutrient uptake in these upland riparian zones. Relative to these biological controls, hydrologic variation played a much less important role in controlling nutrient export from our study plots. Ongoing nutrient accumulation by plant uptake in aggrading forests at Coweeta has been shown over a 20-year period (Knoepp and Swank 1994). Although biomass lost on the Storm hillslope was significantly greater (by sevenfold) than biomass lost on the Cut hillslope, the difference in soilwater nutrient response was proportionally far greater. Moreover, we observed significant $\mathrm{NO}_{3}-\mathrm{N}$ losses to streamwater only in our plot of windthrown and uprooted vegetation, where the soil-root connection was disrupted. 


\section{Implications}

On the basis of this experiment, with respect to control over nutrient flux in upland headwater riparian areas, Rhododendron did not behave like a keystone species. Only small changes in soilwater nutrient concentrations occurred following Rhododendron removal, and none of these reached groundwater or streamwater. In terms of management implications, our recommendation to forest managers is that, with minimal soil disturbance, basal cutting and removal of near-stream Rhododendron understory will not have a significant effect on streamwater quality in first-order watersheds, provided that canopy trees remain, understory root systems are left in place, and removal is accompanied by minimal soil disturbance. If canopy trees have already been removed and near-stream understory Rhododendron is the only remaining vegetation, then our recommendation based on the present study would not apply.

In contrast to the lack of response following Rhododendron removal, a localized uprooting of canopy trees in the near-stream area created large increases of soilwater $\mathrm{NO}_{3}{ }^{-}-\mathrm{N}$, which resulted in a persistent increase in streamwater $\mathrm{NO}_{3}{ }^{-}-\mathrm{N}$. This outcome suggests that nutrient uptake by canopy dominant vegetation, and by their associated soil microbial communities, may provide a key control on $\mathrm{NO}_{3}{ }^{-}$- $\mathrm{N}$ export in riparian zones of upland forests. Disruption of the root-soil connection in dominant trees via uprooting in this study promoted significant nutrient loss to streams. Management strategies for water quality and nutrient retention by riparian vegetation buffers in upland forested watersheds should minimize the removal of dominant canopy trees and pay close attention to preserving existing root-soil integrity.

\section{ACKNOWLEDGMENTS}

This work was supported by the Coweeta LTER (Long Term Ecological Research) Program (National Science Foundation [NSF] grants BSR 9011661 and DEB 96 32854) and partially funded by the USDA, Forest Service, Southern Research Station. Helpful suggestions were received from Cliff Dahm and Jack Stanford during an NSF site review in 1993. Jack Webster provided advice on piezometer construction and installation. Bruce Wallace provided streamflow and streamwater chemistry data from WS 56. Cindy Brown and Carol Harper assisted in the wet chemistry analyses. The late Ian Moore provided TAPES-C software, Keith Beven provided IHDM4 software, and Sue Eggert provided RIA software. Patricia Parola assisted with graphics.
Scott Hill assisted in field collections of soilwater. Devon Helfmeyer, Malia Helfmeyer, Jennifer Knoepp, Kevin Payne, Jason Piluk, Darby Ransom, and Christina Wright assisted in the cutting, removal, and measurement of Rhododendron. Virginia Jin and Denise Palleiko assisted in the mapping of trees after the hurricane blowdown. Robert Naiman and two anonymous reviewers provided comments that greatly improved the manuscript.

\section{REFERENCES}

Aber J, McDowell W, Nadelhoffer K, Magill A, Berntson G, Kamakea M, McNulty S, Currie W, Rustad L, Fernandez I. 1998. Nitrogen saturation in temperate forest ecosystems. BioScience 48:921-34.

Beven KJ, Calver A, Morris EM. 1987. The Institute of Hydrology Distributed Model. Institute of Hydrology Report No. 98. Wallingford (UK): Institute of Hydrology, 33 p.

Carpenter SR, Frost TM, Heisey D, Kratz TK. 1989. Randomized intervention analysis and the interpretation of whole-ecosystem experiments. Ecology 70:1142-52.

Clinton BD, Boring LR, Swank WT. 1993. Regeneration patterns in canopy gaps of mixed-oak forests of the southern Appalachians: influences of topographic position and evergreen understory. Am Midl Nat 132:308-19.

Davidson EA, Swank WT. 1987. Factors limiting denitrification in soils from mature and disturbed southeastern hardwood forests. For Sci 33:135-44.

Davidson EA, Swank WT. 1990. Nitrous oxide dissolved in soil solution: an insignificant pathway of nitrogen loss from a southeastern hardwood forest. Water Resources Res 26:168790

Day FP, McGinty DT. 1975. Mineral cycling strategies of two deciduous and two evergreen tree species on a Southern Appalachian watershed. In: Howell FG, Gentry JB, Smith MH, editors. Mineral cycling in southeastern ecosystems. Springfield (VA): National Technical Information Service. p 736-43.

Fitzgerald JW, Strickland TC, Swank WT. 1982. Metabolic fate of inorganic sulfate in soil samples from undisturbed and managed forest ecosystems. Soil Biol Biochem 14:529-36.

Gregory SV, Swanson FJ, McKee WA, Cummins KW. 1991. An ecosystem perspective of riparian zones. BioScience 41:54051

Hansen EA, Harris AR. 1975. Validity of soil-water samples collected with porous ceramic cups. Soil Sci Soc Am Proc 39:528-36.

Hatcher RD Jr. 1988. Bedrock geology and regional geologic setting of Coweeta Hydrologic Laboratory in the eastern Blue Ridge. In: Swank WT, Crossley DA, editors. Forest hydrology and ecology at Coweeta. New York: Springer-Verlag. p 81-92.

Hedin LO, von Fischer JC, Ostrom NE, Kennedy BP, Brown MG, Robertson GP. 1998. Thermodynamic constraints on nitrogen transformations and other biogeochemical processes at soilstream interfaces. Ecology 79:684-703.

Hornbeck JW, Smith CT, Martin QW, Tritton LM, Pierce RS. 1990. Effects of intensive harvesting on nutrient capitals of three forest types in New England. For Ecol Manage 30:55-64.

Johnson DW, West DC, Todd DE, Mann LK. 1982. Effects of sawlog vs. whole-tree harvesting on the nitrogen, phosphorus, potassium, and calcium budgets of an upland mixed oak forest. Soil Sci Soc Am J 46:1304-9. 
Knoepp JD, Swank WT. 1994. Long-term chemistry changes in aggrading forest ecosystems. Soil Sci Soc Am J 58:325-32.

Likens GE, Bormann FH, Johnson NM, Fisher DW, Pierce RS. 1970. Effects of forest cutting and herbicide treatment on nutrient budgets in the Hubbard Brook watershed-ecosystem. Ecol Monogr 40:23-47.

McDowell WH, McSwiney CP, Bowden WB. 1996. Effects of hurricane disturbance on groundwater chemistry and riparian function in a tropical rain forest. Biotropica 28:577-84.

McGee CE, Smith RC. 1967. Undisturbed Rhododendron thickets are not spreading. J For 65:334-6.

McGinty DT. 1972. The ecological roles of Kalmia latifolia and Rhododendron maximum in the hardwood forest at Coweeta [thesis]. Athens, (GA): University of Georgia.

Martin JG, Kloeppel BD, Schaefer TL, Kimbler DL, McNulty SG. 1998. Aboveground biomass and nitrogen allocation of ten deciduous southern Appalachian tree species. Can J For Res 28:1648-59.

Meyer JL, Tate CM. 1983. The effects of watershed disturbance on dissolved organic carbon dynamics of a stream. Ecology 64:33-44.

Mitchell MJ, Driscoll CT, Fuller RD, David MB, Likens GE. 1989. Effect of whole-tree harvesting on the sulfur dynamics of a forest soil. Soil Sci Soc Am J 53:933-40.

Monk CD, McGinty DT, Day FP. 1985. The ecological importance of Kalmia latifolia and Rhododendron maximum in the deciduous forest of the southern Appalachians. Bull Torrey Bot Club 112:187-93.

Moore ID, Grayson RB. 1991. Terrain-based catchment partitioning and runoff prediction using vector elevation data. Water Resources Res 27:1177-91.

Mulholland PJ, Hill WR. 1997. Seasonal patterns in streamwater nutrient and dissolved organic carbon concentrations: separating catchment flow path and in-stream effects. Water Resources Res 33:1297-306.

Naiman RJ, Décamps H. 1997. The ecology of interfaces: riparian zones. Annu Rev Ecol Syst 28:621-58.

Nilsen ET. 1986. Quantitative phenology and leaf survivorship of Rhododendron maximum in contrasting irradiance environments of the southern Applachian mountains. Am J Bot 73:822-31.

Nodvin SC, Driscoll CT, Likens GE. 1988. Soil processes and sulfate loss at the Hubbard Brook Experimental Forest. Biogeochemistry 5:185-99.

Peterjohn WT, Correll DL. 1984. Nutrient dynamics in an agricultural watershed: observations on the role of a riparian forest. Ecology 65:1466-75.

Phillips DL, Murdy WH. 1985. Effects of rhododendron (R. maximum L.) on regeneration of southern Appalachian hardwoods. For Sci 31:226-33.
Pye JM, Vitousek PM. 1985. Soil and nutrient removals by erosion and windrowing at a southeastern U.S. Piedmont site. For Ecol Manage 11:145-55.

Rutter AJ, Morton AJ, Robins PC. 1975. A predictive model of rainfall interception in forests, II: generalization of the model and comparison with observations in some coniferous and hardwood stands. J Appl Ecol 12:367-80.

Sharitz RR, Boring LR, Van Lear DH, Pinder JE. 1992. Integrating ecological concepts with natural resource management of southern forests. Ecol Appl 2:226-37.

Swank WT. 1986. Biological control of solute losses from forest ecosystems. In: Trudgill ST, editor. Solute processes. New York: Wiley. p 85-139.

Swank WT. 1988. Stream chemistry responses to disturbance. In: Swank WT, Crossley DA, editors. Forest hydrology and ecology at Coweeta. New York: Springer-Verlag. p 339-57.

Swank WT, Vose JM. 1997. Long-term nitrogen dynamics of Coweeta forested watersheds in the southern United States of America. Global Biogeochem Cycles 11:657-71.

Swift LW, Cunningham GB, Douglas JE. 1988. Climatology and hydrology. In: Swank WT, Crossley DA, editors. Forest hydrology and ecology at Coweeta. New York: Springer-Verlag. p 35-55.

Topp GC, Davis JL, Annan AP. 1985. Measurement of soil water content using time-domain reflectometry. Soil Sci Soc Am J 49:19-24.

Vitousek PM, Gosz JR, Grier CC, Melillo JM, Reiners WA. 1982. A comparative analysis of potential nitrification and nitrate mobility in forest ecosystems. Ecol Monogr 52:155-77.

Vose JM, Deal JM, Brown C, Harper C. 2002. Procedures for chemical analysis. Otto (NC): Coweeta Hydrologic Laboratory. 172 p. Available online at: <http://coweeta.ecology.uga.edu/ webdocs $>$.

Wright CJ, Coleman DC. 2002. Responses of soil microbial biomass, nematode trophic groups, N-mineralization and litter decomposition to disturbance events in the southern Appalachians. Soil Biol Chem 34:13-25.

Yeakley JA, Hornberger GM, Swank WT, Bolstad PV, Vose JM. 2000. Soil moisture modeling in humid mountainous landscapes. In: Wilson JP, Gallant JC, editors. Terrain analysis: principles and applications. New York: Wiley. p 225-53.

Yeakley JA, Meyer JL, Swank WT. 1994. Hillslope nutrient flux during near-stream vegetation removal I: a multi-scaled modeling design. Water Air Soil Pollu 77:229-46.

Yeakley JA, Swank WT, Swift LW, Hornberger GM, Shugart HH. 1998. Soil moisture gradients and controls on a southern Appalachian hillslope from drought through recharge. Hydrol Earth Syst Sci 2:41-9. 